\title{
UDC 004.7.032.26:656.222.3
}

\author{
V. M. PAKHOMOVA ${ }^{1 *}$, Y. S. MANDYBURA ${ }^{2 *}$ \\ ${ }^{1 *}$ Dep. «Electronic Computing Machines», Dnipro National University of Railway Transport named after Academician \\ V. Lazaryan, Lazaryana St., 2, 49010, Dnipro, Ukraine, tel. +38 (056) 373 15 89, e-mail viknikpakh@ gmail.com, \\ ORCID 0000-0002-0022-099X \\ ${ }^{2 *}$ Dep. «Electronic Computing Machines», Dnipro National University of Railway Transport named after Academician \\ V. Lazaryan, Lazaryana St., 2, 49010, Dnipro, Ukraine, tel. +38 (056) 373 15 89, e-mail mandybura1994@ gmail.com, \\ ORCID 0000-0002-7134-9416
}

\section{OPTIMAL ROUTE DEFINITION IN THE RAILWAY INFORMATION NETWORK USING NEURAL-FUZZY MODELS}

Purpose. Modern algorithms for choosing the shortest route, for example, the Bellman-Ford and Dijkstra algorithms, which are currently widely used in existing routing protocols (RIP, OSPF), do not always lead to an effective result. Therefore, there is a need to study the possibility of organizing routing in in the railway network of information and telecommunication system (ITS) using the methods of artificial intelligence. Methodology. On the basis of the simulation model created in the OPNET modeling system a fragment of the ITS railway network was considered and the following samples were formed: training, testing, and control one. For modeling a neural-fuzzy network (hybrid system) in the the MatLAB system the following parameters are input: packet length (three term sets), traffic intensity (five term sets), and the number of intermediate routers that make up the route (four term sets). As the resulting characteristic, the time spent by the packet in the routers along its route in the ITS network (four term sets) was taken. On the basis of a certain time of packet residence in the routers and queue delays on the routers making up different paths (with the same number of the routers) the optimal route was determined. Findings. For the railway ITS fragment under consideration, a forecast was made of the packet residence time in the routers along its route based on the neural-fuzzy network created in the MatLAB system. The authors conducted the study of the average error of the neural-fuzzy network`s training with various membership functions and according to the different methods of training optimization. It was found that the smallest value of the average learning error is provided by the neuro-fuzzy network configuration 3-12-60-60-1 when using the symmetric Gaussian membership function according to the hybrid optimization method. Originality. According to the RIP and OSPF scenarios, the following characteristics were obtained on the simulation model created in the OPNET simulation system: average server load, average packet processing time by the router, average waiting time for packets in the queue, average number of lost packets, and network convergence time. It was determined that the best results are achieved by the simulation network model according to the OSPF scenario. The proposed integrated routing system in the ITS network of railway transport, which is based on the neural-fuzzy networks created, determines the optimal route in the network faster than the existing OSPF routing protocol. Practical value. An integrated routing system in the ITS system of railway transport will make it possible to determine the optimal route in the network with the same number of the routers that make up the packet path in real time.

Keywords: routing; OSPF protocol; simulation model; hybrid system; term; membership function; sample; error

\section{Introduction}

At present, various scientists have been searching for a solution of the routing problem in the computer networks based on the use of neural networks $[1,3-4,6,14,19]$. The first such attempt was made by Hopfield to solve the traveling salesman problem [11]. Pavlenko M. A. analyzed the possibilities of some neural networks: multilayer perceptron, Hopfield network, RBF network for organizing routing of five routers [6]. It has been established that the most promising way to solve the routing problem is the Hopfield's network, which is able to operate in real time, but in the case of using it one needs to conduct additional studies of the transfer functions of neurons and the energy function of the neural network $[4,8,11$, 18].

In turn, fuzzy neural networks (hybrid systems) are designed to combine the benefits of neural networks and fuzzy inference systems [13, 17]. This makes it possible to develop and submit the systems models in the form of fuzzy product rules to construct which the capabilities of the neural 
networks are used. For example, the AdaptiveNetwork-Based Fuzzy Inference System (ANFIS) implemented in the MatLAB Fuzzy Logic Toolbox application [9-10]. In the work [2], in particular, Kovalenko T. A. determined the route in the computer network based on the neural fuzzy network, to the input of which the following parameters are supplied: number of transitions, data transmission speed; as a resultant characteristic the time of the packet residence in the route was taken. But it is appropriate for the railway ITS network to consider a change in the traffic intensity rather than a data transmission speed that requires the construction of a neural network of another structure. In addition, based on the estimated packet transmission time in the network, it is advisable to determine the route itself, provided the same number of routers on the paths of the packet, which also requires the creation of additional neural network.

Previously, the authors of the works [7, 15-16, $20]$ have already presented the results of studies of the use of intellectual means in the railway ITS network: Hopfield network and multi-layer neural network, ant and genetic methods. In addition, the possibility of using the RIP protocol in the Prydniprovska Railway network on a software model was investigated. But nowadays, new modeling systems have emerged that allow us to create simulation models of networks and conduct research on them. Among them, the OPNET Modeler system [5, 12], which combines analytical methods and simulation tools.

\section{Purpose}

In our work, we envisage for the railway ITS network to develop a methodology for determining the optimal route based on the use of fuzzy neural networks. For their modeling to generate samples on a simulation model of the railway ITS network fragment created in the OPNET Modeler system.

\section{Methodology}

Problem statement. Today, the railway transport ITS network, the fragment of which is presented in Fig. 1, is being constructed based on an optical transport network. Conceptually, to construct a single data network of Ukrzaliznytsia, Cisco network equipment was selected, which is a single hardware and software complex. At the present stage in the railway ITS network, the router performs OSPF (Open Shortest Path First) protocol, as it is a common standard supported by various network equipment manufacturers and avoids closed loops during development of the data transmission networks at the railway transport of Ukraine.

Given that the packet transmission time on the network channel is much shorter, it is only advisable to consider the packet residence time on the routers that make up its path in the ITS network. Given that the packets are received by the router according to the Poisson law and the distribution of processing time is exponential, we have the $\mathrm{M} / \mathrm{M} / 1$ model. Then the packet residence time on the router is calculated in the following way:

$$
t_{i}=t_{i}^{w}+t_{i}^{p r}
$$

where $t_{i}$ - package residence time on the $i$-th router, $\mu \mathrm{s} ; t_{i}^{w}$-packet waiting time in the queue on the $i$-th router, $\mu \mathrm{s} ; t_{i}^{p r}$ - packet processing time by the i-th router, $\mu$ s.

In turn, the processing time of packet by the $i$ th router can be calculated by the well-known formula:

$$
t_{i}^{p r}=\frac{L^{p a c}}{V},
$$

where $L^{p a c}$ - packet length, byte; $V$ - the rate of data staging by the router, Mbps (in particular for Fast Ethernet $100 \mathrm{Mbps}$ ).

The number of packets processed by the $i$-th router will be:

$$
\rho_{i}=\lambda_{i} \cdot t_{i}^{p r}
$$

where $\lambda_{i}-$ the intensity of packets receipt to the $i$ th router, packet/s.

Then the calculation of the packet waiting time in the queue on the $i$-th router is calculated by the following formula:

$$
t_{i}^{w}=\frac{\rho_{i} \cdot t_{i}^{p r}}{1-\rho_{i}} .
$$


It is necessary to determine the optimal route of packet in the railway ITS network provided that:

$$
\sum_{i=1}^{K} t_{i} \rightarrow \min
$$

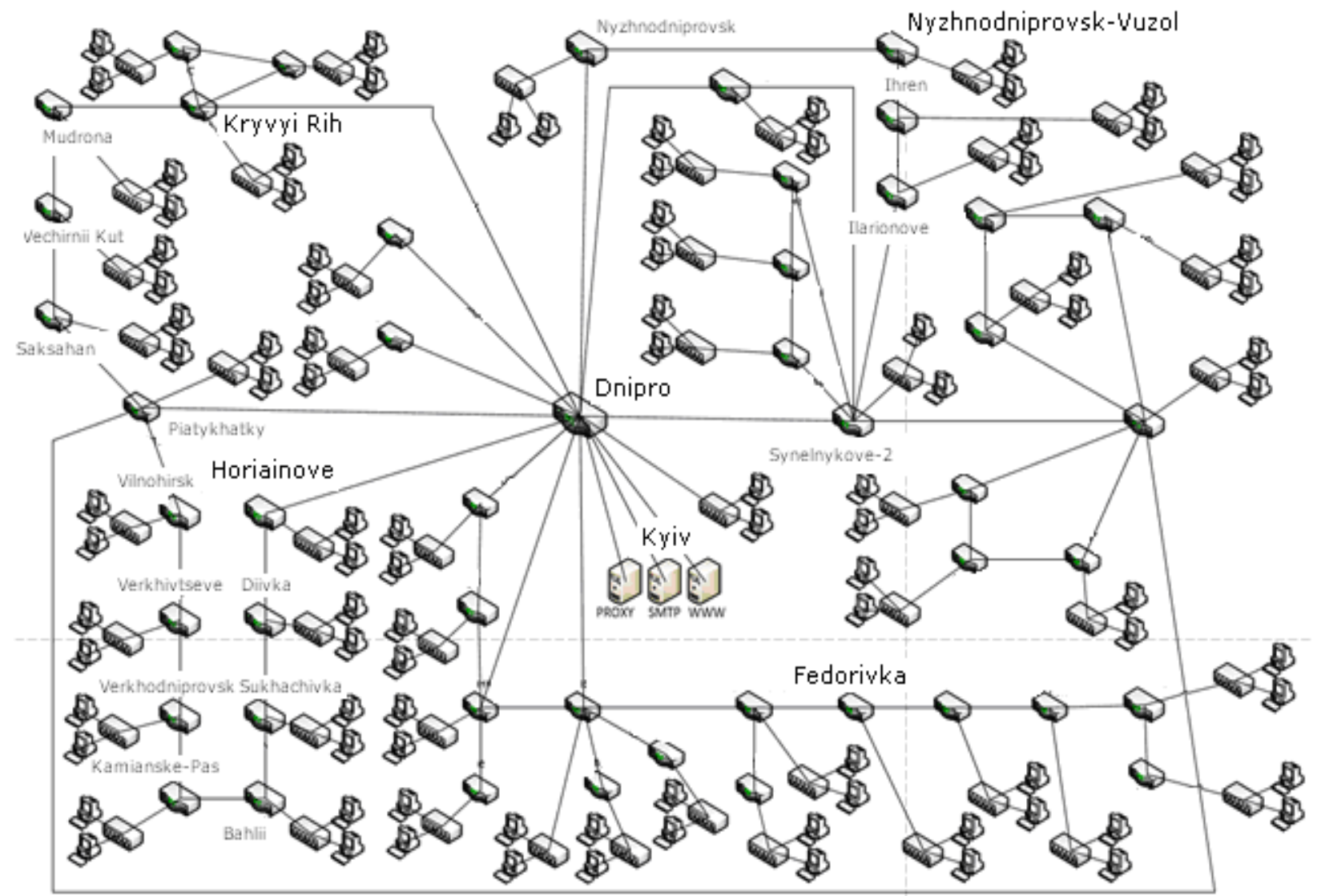

Fig. 1. The structure of the railway ITS network fragment under consideration:
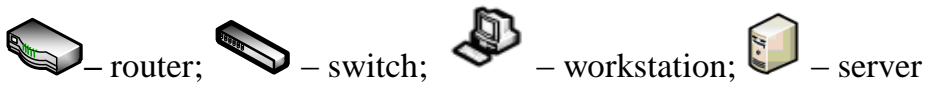

Creating a simulation model. In the OPNET Modeler simulation system a simulation model of the ITS railway network fragment was created, the structure of which is presented in Fig. 2, according to the structure of the ITS network (see Fig. 1).

Two scenarios have been created on the Fast Ethernet simulation model at the ITS of Prydniprovska Railway: RIP and OSPF protocol. The study (within five minutes) of the following characteristics was performed: average load of the where $K-$ is the number of intermediate routers that make up the packet path. 


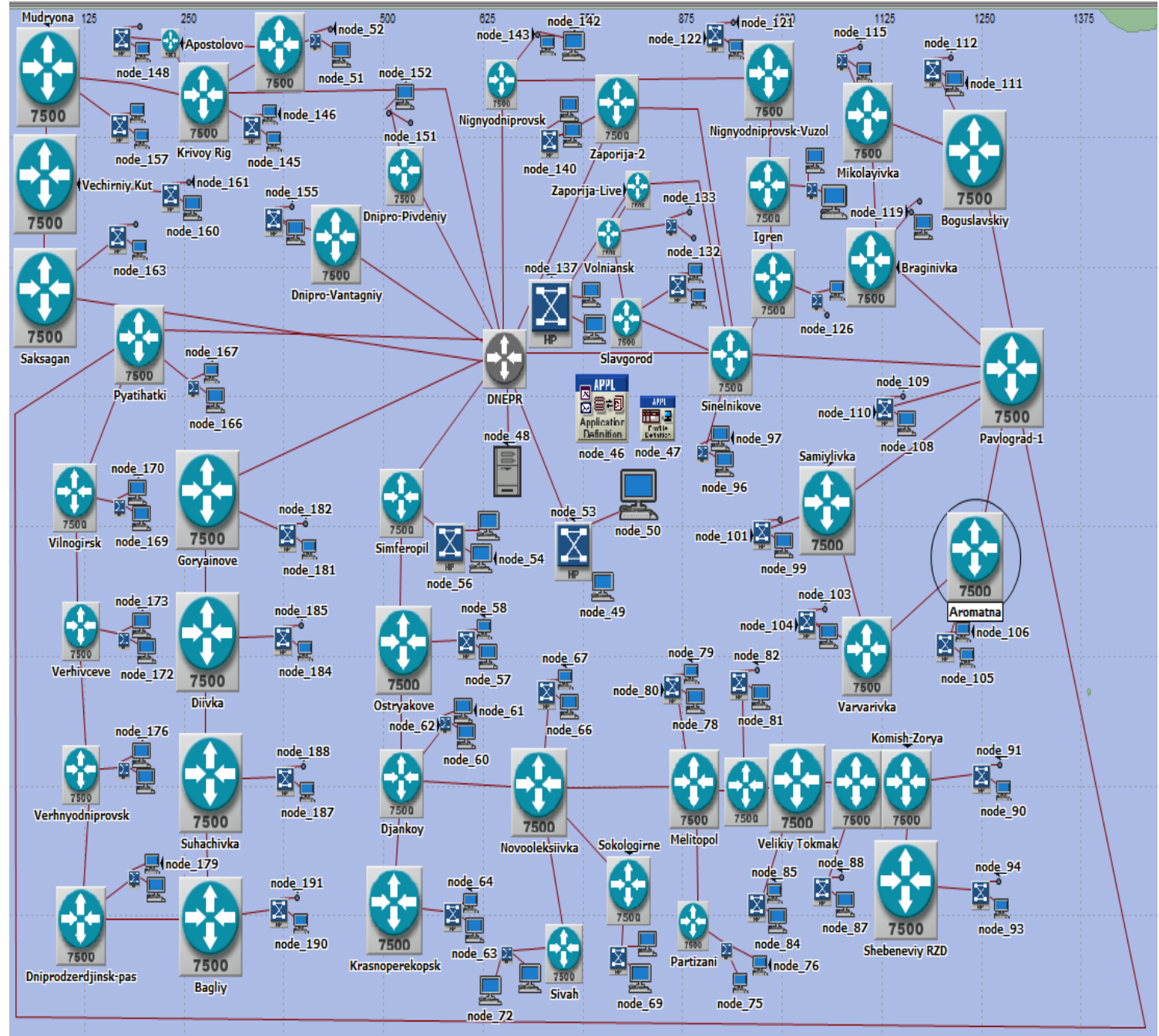

Fig. 2. Simulation model in the OPNET Modeler:

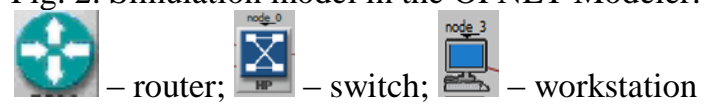

Fig. 3 shows that the worst results are obtained by the network simulation model according to the RIP scenario: server load increases rapidly (on average, about by 3 times per minute); packet processing time by the router takes much longer (approximately by 0.5 times per minute); the packet waiting time in the queue is always greater (about by 1.6 times per minute); packet losses increase rapidly (on average by 3.5 times per minute); the network convergence time is almost twice as large. As an example, the average waiting time of packets in the queue and the average number of packets lost on the router are shown, Fig. 3. Regardless of the routing protocol (RIP or OSPF): the longer the waiting time for packets in the queue (Fig. 3,a), the higher the number of lost packets (Fig. 3, b).

Determining the packet residence time on the routers based on the use of Neural Fuzzy Network (NN1). The following variables are used as the input parameters: $x_{1}$ - packet length $(L M$, $L C, L) ; x_{2}-$ traffic intensity $(\Lambda M, \Lambda M b, \Lambda C$, $\Lambda C b, \Lambda$ ); $x_{3}$ - number of transitions (number of intermediate routers that make up the packet route) $(K 1, K 2, K 3, K 4)$. The packet residence time in the routers on the route of its transmission in the ITS network $(T 1, T 2, T 3, T 4)$ is taken as the resultant characteristic $y$. The values of the term sets used for linguistic evaluation of input and output variables are summarized in Table 1 . 


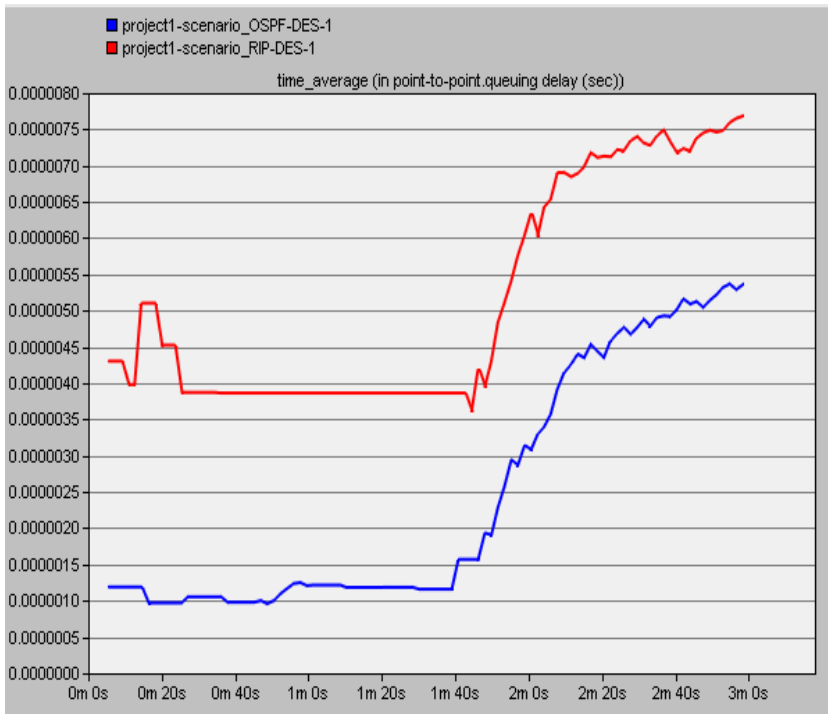

Fig. 3. The experiment results on a simulation model:

$a$-the average waiting time for packets in a queue; $b$ - the average number of packets lost on the router

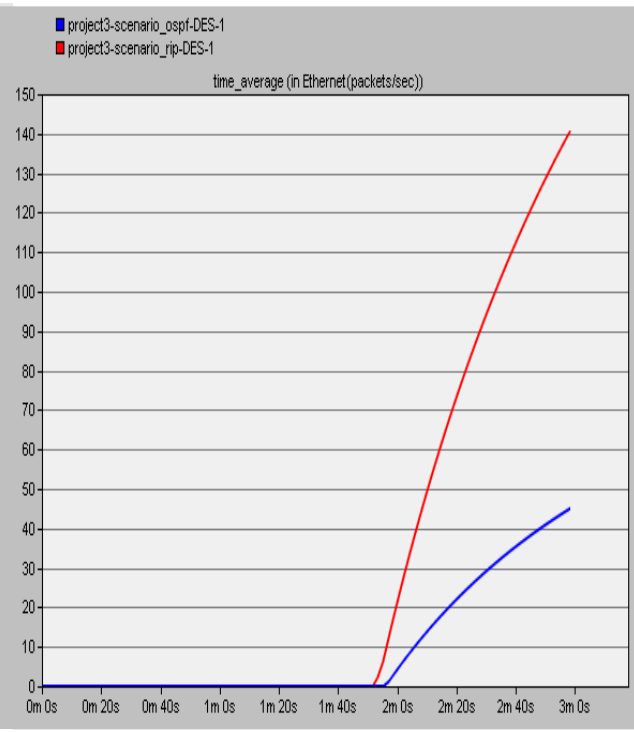

Table 1

Linguistic evaluation of input and output variables for NN1

\begin{tabular}{c|c|c|c}
\hline \multicolumn{2}{c|}{ Input variables } & Output variable \\
\hline $\begin{array}{c}\text { Packet length, } \\
\text { bytes }\end{array}$ & $\begin{array}{c}\text { Traffic intensity, } \\
\text { packet/s }\end{array}$ & $\begin{array}{c}\text { Number of tran- } \\
\text { sitions }\end{array}$ & $\begin{array}{c}\text { Packet residence time on } \\
\text { the routers on the route, } \\
\mu \text { s }\end{array}$ \\
\hline$L M: 70-500$ & $\Lambda M: 10-200$ & $K 1: 1$ & $T 1: 5,6-140$ \\
$L C: 501-1000$ & $\Lambda M b: 201-400$ & $K 2: 2$ & $T 2: 141-275$ \\
$L: 1001-1500$ & $\Lambda C: 401-600$ & $K 3: 3$ & $T 3: 276-410$ \\
& $\Lambda C b: 601-800$ & $K 4: 4$ & $T 4: 411-545$
\end{tabular}

The number of fuzzy product rules depends on the number of input variables and the number of terms and is $3 \cdot 5 \cdot 4=60$ rules. The rule base fragment is presented below:

if $x_{1}=L M$ I $x_{2}=\Lambda M$ I $x_{3}=K 1$, then $y=T 1$;

if $x_{1}=L M$ I $x_{2}=\Lambda M$ I $x_{3}=K 2$, then $y=T 3$;

if $x_{1}=L M$ I $x_{2}=\Lambda M$ I $x_{3}=K 3$, then $y=T 1$;

if $x_{1}=L M$ I $x_{2}=\Lambda M$ I $x_{3}=K 4$, then $y=T 4$;

if $x_{1}=L M$ I $x_{2}=\Lambda M b$ I $x_{3}=K 1$, then $y=T 1$;

if $x_{1}=L M$ I $x_{2}=\Lambda M b$ I $x_{3}=K 2$, then $y=T 3$;

if $x_{1}=L M$ I $x_{2}=\Lambda M b$ I $x_{3}=K 3$, then $y=T 1$;

if $x_{1}=L M$ I $x_{2}=\Lambda M b$ I $x_{3}=K 4$, then $y=T 4$;

if $x_{1}=L M$ I $x_{2}=\Lambda C$ I $x_{3}=K 1$, then $y=T 1$.
The structure of the corresponding NN1 is shown in Fig. 4. Layer 1 contains neurons that represent membership functions of the input fuzzy variables and perform the operation of fuzzification (making fuzzy) of the input data. Layer 2 contains neurons that store the correct values for the rules that make up the knowledge base created by the model's training; these neurons may contain any variant of the realization of the $t$-norm operation, which is a fuzzy analogue of «AND» (logical operation «AND»). Neurons of the layer 3 contain the results of calculations of rules, taking into account the weight of each rule. Neurons of the layer 4 contain the final results of the rules`calculations, 


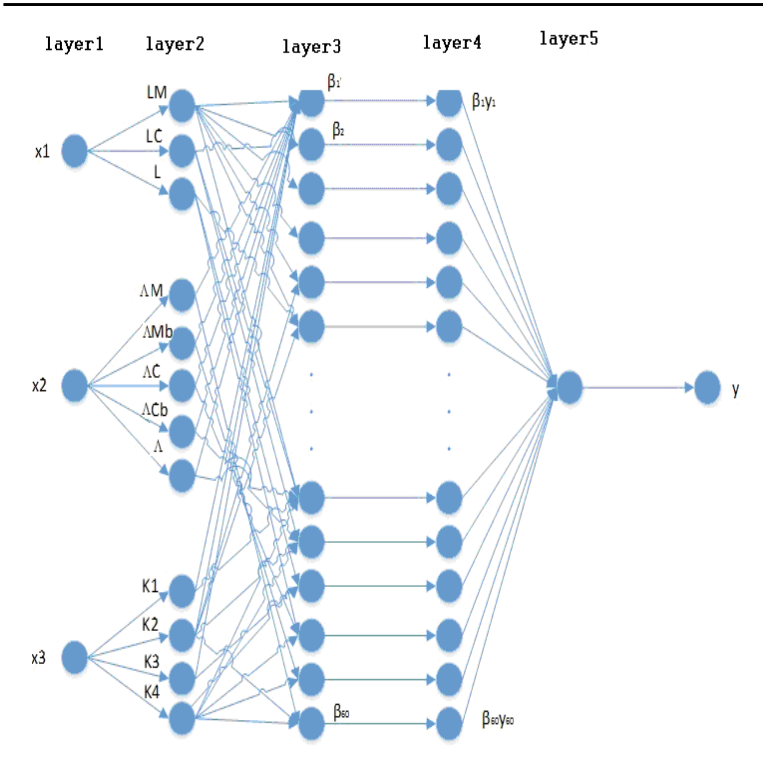

which are grouped into fuzzy classes. Layer 5 contains only one neuron that calculates the final model output by performing a defuzzification (making clear) by determining the centers of fuzzy classes.

Formation of samples for the NN1. The following samples for the NN1 were formed: a training sample of 60 examples (a fragment of which is given in Table 2), a test sample of 24 examples and a control sample of 12 examples (Table 3 ).

Fig. 4. NN1 structure

Table 2

Fragment of training sample for the NN1

\begin{tabular}{|c|c|c|c|c|c|c|c|}
\hline $\begin{array}{c}\text { Packet } \\
\text { length, } \\
\text { bytes }\end{array}$ & $\begin{array}{c}\text { Traffic } \\
\text { intensity, } \\
\text { packet/sec }\end{array}$ & $\begin{array}{l}\text { Number } \\
\text { of transi- } \\
\text { tions }\end{array}$ & $\begin{array}{l}\text { Packet time in the } \\
\text { routers on the } \\
\text { route, } \mu \mathrm{s}\end{array}$ & $\begin{array}{c}\text { Packet } \\
\text { length, } \\
\text { bytes }\end{array}$ & $\begin{array}{c}\text { Traffic } \\
\text { intensity, } \\
\text { packet/sec }\end{array}$ & $\begin{array}{l}\text { Num- } \\
\text { ber of } \\
\text { tran- } \\
\text { si- } \\
\text { tions }\end{array}$ & $\begin{array}{l}\text { Package time in } \\
\text { the routers on the } \\
\text { route, } \mu \mathrm{s}\end{array}$ \\
\hline 70 & 10 & 1 & 5.6 & 70 & 1000 & 1 & 5,6 \\
\hline 500 & 10 & 1 & 40 & 500 & 1000 & 1 & 42 \\
\hline 1000 & 10 & 1 & 80 & 1000 & 1000 & 1 & 87 \\
\hline 1500 & 10 & 1 & 120 & 1500 & 1000 & 1 & 136 \\
\hline 70 & 10 & 2 & 11.2 & 70 & 1000 & 2 & 11 \\
\hline 500 & 10 & 2 & 80 & 500 & 1000 & 2 & 83 \\
\hline 1000 & 10 & 2 & 160 & 1000 & 1000 & 2 & 174 \\
\hline 1500 & 10 & 2 & 360 & 1500 & 1000 & 2 & 273 \\
\hline 70 & 10 & 3 & 16.8 & 70 & 1000 & 3 & 17 \\
\hline 500 & 10 & 3 & 120 & 500 & 1000 & 3 & 125 \\
\hline 1000 & 10 & 3 & 240 & 1000 & 1000 & 3 & 261 \\
\hline 1500 & 10 & 3 & 360 & 1500 & 1000 & 3 & 409 \\
\hline 70 & 10 & 4 & 22.4 & 70 & 1000 & 4 & 23 \\
\hline 500 & 10 & 4 & 160 & 500 & 1000 & 4 & 167 \\
\hline 1000 & 10 & 4 & 320 & 1000 & 1000 & 4 & 348 \\
\hline 1500 & 10 & 4 & 480 & 1500 & 1000 & 4 & 545 \\
\hline
\end{tabular}


Test and control samples for the NN1

\begin{tabular}{|c|c|c|c|c|c|c|c|}
\hline \multicolumn{4}{|c|}{ Test sample } & \multicolumn{4}{|c|}{ Control sample } \\
\hline $\begin{array}{l}\text { Packet } \\
\text { length, } \\
\text { bytes }\end{array}$ & $\begin{array}{c}\text { Traffic } \\
\text { intensity, } \\
\text { packet/sec }\end{array}$ & $\begin{array}{l}\text { Number of } \\
\text { transitions }\end{array}$ & $\begin{array}{l}\text { Package time in } \\
\text { the routers on the } \\
\text { route, } \mu \mathrm{s}\end{array}$ & $\begin{array}{l}\text { Packet } \\
\text { length, } \\
\text { bytes }\end{array}$ & $\begin{array}{c}\text { Traffic } \\
\text { intensity, } \\
\text { packet/sec }\end{array}$ & $\begin{array}{l}\text { Number of } \\
\text { transitions }\end{array}$ & $\begin{array}{l}\text { Package time in the } \\
\text { routers on the route, } \\
\mu \mathrm{s}\end{array}$ \\
\hline 500 & 300 & 1 & 40 & 500 & 500 & 1 & 41 \\
\hline 1000 & 300 & 1 & 82 & 1000 & 500 & 1 & 83 \\
\hline 1500 & 300 & 1 & 124 & 1500 & 500 & 1 & 128 \\
\hline 500 & 300 & 2 & 81 & 500 & 500 & 2 & 82 \\
\hline 1000 & 300 & 2 & 163 & 1000 & 500 & 2 & 167 \\
\hline 1500 & 300 & 2 & 373 & 1500 & 500 & 2 & 255 \\
\hline 500 & 300 & 3 & 121 & 500 & 500 & 3 & 122 \\
\hline 1000 & 300 & 3 & 245 & 1000 & 500 & 3 & 250 \\
\hline 1500 & 300 & 3 & 373 & 1500 & 500 & 3 & 383 \\
\hline 500 & 300 & 4 & 162 & 500 & 500 & 4 & 163 \\
\hline 1000 & 300 & 4 & 328 & 1000 & 500 & 4 & 333 \\
\hline 1500 & 300 & 4 & 498 & 1500 & 500 & 4 & 511 \\
\hline 500 & 700 & 1 & 41 & & & & \\
\hline 1000 & 700 & 1 & 85 & & & & \\
\hline 1500 & 700 & 1 & 131 & & & & \\
\hline 500 & 700 & 2 & 82 & & & & \\
\hline 1000 & 700 & 2 & 169 & & & & \\
\hline 1500 & 700 & 2 & 393 & & & & \\
\hline 500 & 700 & 3 & 123 & & & & \\
\hline 1000 & 700 & 3 & 254 & & & & \\
\hline 1500 & 700 & 3 & 393 & & & & \\
\hline 500 & 700 & 4 & 165 & & & & \\
\hline 1000 & 700 & 4 & 339 & & & & \\
\hline 1500 & 700 & 4 & 524 & & & & \\
\hline
\end{tabular}

Training and testing the NN1. The Neural Networks Toolbox, which is a part of MatLAB, has more than 160 different functions that make it possible to create, train, and research neural networks. In addition, the ANFIS for MatLAB supports almost complete automation of the NN crea- tion process, which allows to construct the $\mathrm{NN}$ configuration 3-12-60-60-1, using the Sugeno algorithm. 100 cycles (Epochs) are set for NN1 training; the error of the NN1 training according to the hybrid method is $8.4873 \cdot 10^{-10} \mathrm{sec}$. 
On the network simulation model, constructed in the ORNET, with a packet length of 550 bytes, traffic intensity of 10 packets/sec and three transitions, the packet residence time on the routers in the ITS railway transport network is $0.000132 \mathrm{sec}$. To test the constructed NN1, let us run it with in- put data that are not in any of the samples. The simulation is displayed in a graphical window (Fig. 5), where the path of the logical inference by each rule, the resultant fuzzy set are presented, and the deffuzzification procedure is performed.

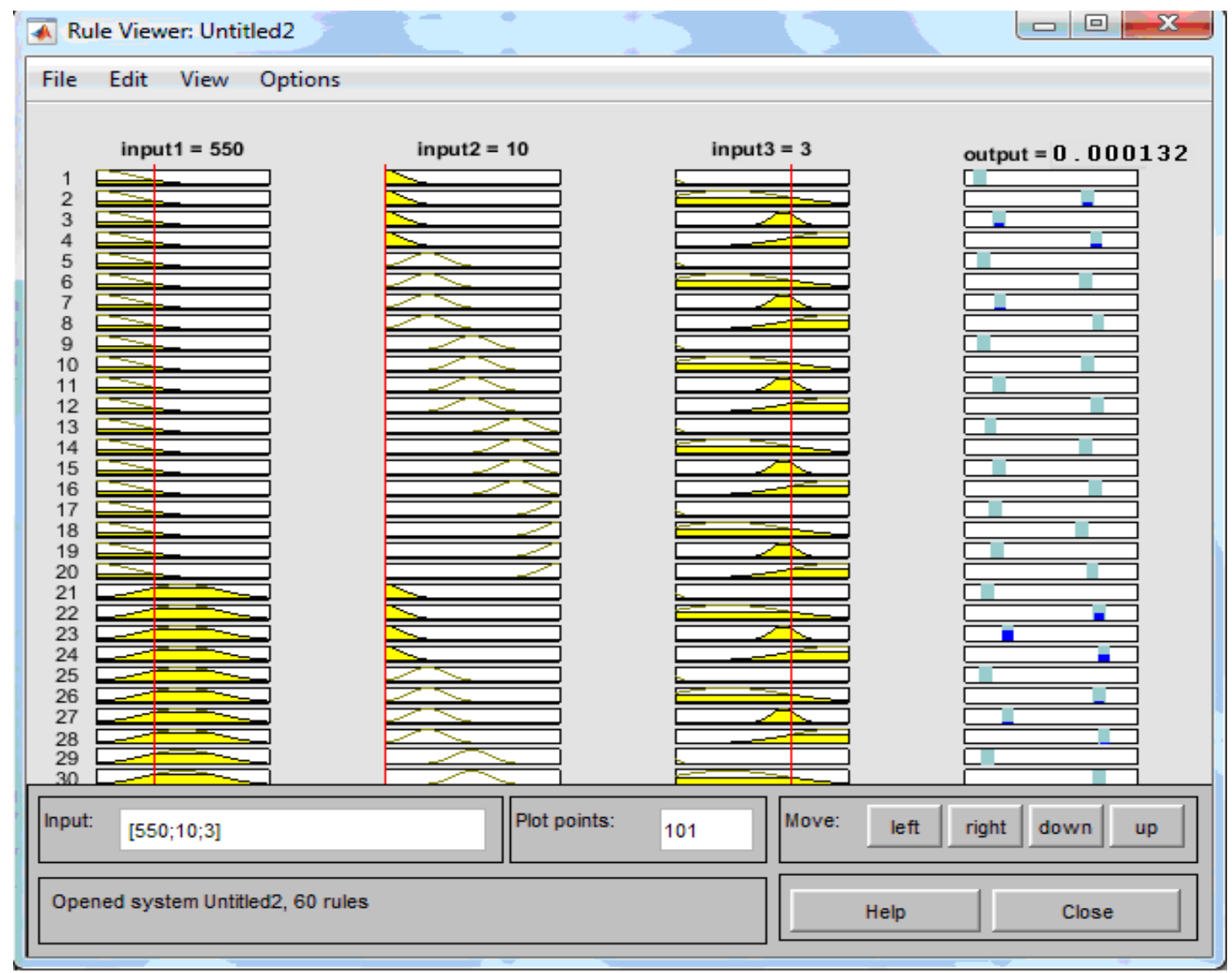

Fig. 5. System of fuzzy output NN1

Each rule of the knowledge base is represented as a sequence of horizontally arranged curves. The resulting fuzzy set is shown in the lower rectangle of the last column of the graphical window. In the same rectangle, the red vertical line corresponds to the clear value of the logical inference obtained from the deffuzzification. According to the input data $[550 ; 10 ; 3]$ the NN1 displays the packet residence time on the routers according to the path of its transmission, equal to $0.000132 \mathrm{~s}$ (Fig. 6). That is, NN1 is properly constructed and trained.
Route definition based on the use of a neural fuzzy network (NN2). The following variables are used as input parameters: $x_{1}-$ is the packet residence time on the routers according to the packet transmission route ( $T \mathrm{~min}, T \mathrm{avg}, T \max$ ); $x_{2}-$ is the total queue delay on the routers on the route $A$ (ZAmin, ZAma, ZAavg, ZAam, ZAmax); $x_{3}-$ is the total queue delay on the routers on the route $B$ (ZBmin, ZBma, ZBavg, ZBam, ZBmax) ; $y$-is the optimal route: 1 (path $A$ ), 2 (path $B$ ). All values are summarized in Table 4. 


\section{Linguistic evaluation of input and output variables for NN2}

\begin{tabular}{|c|c|c|c|}
\hline \multicolumn{3}{|c|}{ Input variables } & Output variable \\
\hline $\begin{array}{l}\text { Packet residence time in the } \\
\text { routers on the route, } \mu \text { s }\end{array}$ & $\begin{array}{c}\text { Total queue delay on the routers } \\
\text { on the path } A, \mu \mathrm{s}\end{array}$ & $\begin{array}{c}\text { Total queue delay on the routers } \\
\text { on the path } B, \mu \text { s }\end{array}$ & Route \\
\hline $\begin{array}{l}\text { Tmin: } 5,6-185 \\
\text { Tavg: } 186-365 \\
T \max : 366-545\end{array}$ & $\begin{array}{c}Z A \min : 0-13 ; \\
Z A \text { ma: } 14-27 ; Z A \operatorname{avg}: 28- \\
\text { 41; ZAam: } 42-55 ; \\
Z A \max : 56-70\end{array}$ & $\begin{array}{c}\text { ZBmin: } 0-13 ; \\
\text { ZBma: } 14-27 ; Z \text { Bavg: } 28- \\
\text { 41; ZBam: } 42-55 ; \\
\text { ZBmax: } 56-70\end{array}$ & $\begin{array}{l}A: 1 \\
B: 2\end{array}$ \\
\hline
\end{tabular}

The number of fuzzy product rules depends on the number of input variables and the number of terms, this value is $3 \cdot 5 \cdot 5=75$ rules. The rule base fragment is given below:

if $x_{1}=T \min \mathrm{I} x_{2}=Z A \min \mathrm{I} x_{3}=Z B \mathrm{~min}$, then $y=B$;

if $x_{1}=T \min \mathrm{I} x_{2}=Z A \min \mathrm{I} x_{3}=Z B$ ma, then $y=B$;

if $x_{1}=T \min \mathrm{I} x_{2}=\mathrm{Z} A \mathrm{~min} \mathrm{I} x_{3}=\mathrm{Z} B$ avg, then $y=B$;

if $x_{1}=T \min I x_{2}=Z A \min \mathrm{I} x_{3}=Z B \mathrm{am}$, then $y=B$;

if $x_{1}=T \min I x_{2}=Z A \min I x_{3}=Z B \max$, then $y=B$;

if $x_{1}=T$ min I $x_{2}=Z A$ ma I $x_{3}=Z B \min$, then $y=A$;

if $x_{1}=T \min \mathrm{I} x_{2}=Z A$ ma I $x_{3}=Z B$ ma, then $y=B$;

if $x_{1}=T \mathrm{~min} I x_{2}=Z A$ ma I $x_{3}=Z B$ avg, then $y=B$;

if $x_{1}=T$ min I $x_{2}=Z A$ ma I $x_{3}=Z B$ am, then $y=B$.

The structure of the corresponding NN2 is shown in Fig. 6.

Formation of the samples NN2. The following samples were formed: a training sample of 75 examples, a test sample of 20 examples and a control of 10 examples (Table 5).

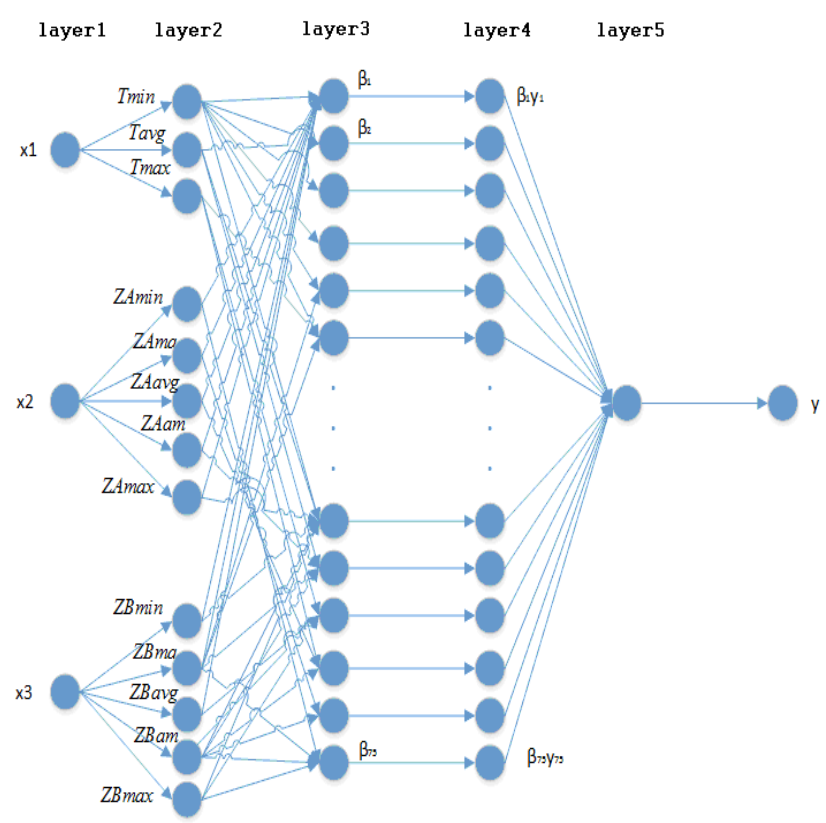

Fig. 6. NFN2 structure

Table 5

Samples fragments for NN2

\begin{tabular}{|c|c|c|c|c|c|c|c|c|c|c|c|}
\hline \multicolumn{4}{|c|}{ Training sample } & \multicolumn{4}{|c|}{ Test sample } & \multicolumn{4}{|c|}{ Control sample } \\
\hline \multirow{2}{*}{$\begin{array}{l}\text { Packet resi- } \\
\text { dence time on } \\
\text { the routers, } \mu \mathrm{s}\end{array}$} & \multicolumn{2}{|c|}{$\begin{array}{l}\text { Total queue } \\
\text { delay, } \mu \text { s }\end{array}$} & \multirow{2}{*}{ Route } & \multirow{2}{*}{$\begin{array}{l}\text { Packet resi- } \\
\text { dence time } \\
\text { on the rout- } \\
\quad \text { ers, } \mu \mathrm{s}\end{array}$} & \multicolumn{2}{|c|}{$\begin{array}{l}\text { Total queue } \\
\text { delay, } \mu \text { s }\end{array}$} & \multirow{2}{*}{ Route } & \multirow{2}{*}{$\begin{array}{l}\text { Packet resi- } \\
\text { dence time } \\
\text { on the rout- } \\
\text { ers, } \mu \text { s }\end{array}$} & \multicolumn{2}{|c|}{$\begin{array}{l}\text { Total queue } \\
\text { delay, } \mu \text { s }\end{array}$} & \multirow{2}{*}{ Route } \\
\hline & $\begin{array}{c}\text { path } \\
A\end{array}$ & $\begin{array}{c}\text { path } \\
B\end{array}$ & & & $\begin{array}{c}\text { path } \\
A\end{array}$ & $\begin{array}{c}\text { path } \\
B\end{array}$ & & & $\begin{array}{c}\text { path } \\
A\end{array}$ & $\begin{array}{c}\text { path } \\
B\end{array}$ & \\
\hline 5.6 & 0 & 14 & $A$ & 7 & 4 & 20 & $A$ & 10 & 11 & 69 & $A$ \\
\hline 5.6 & 14 & 0 & $B$ & 80 & 20 & 4 & $B$ & 68 & 69 & 11 & $B$ \\
\hline 185 & 15 & 29 & $A$ & 150 & 20 & 38 & $A$ & 126 & 15 & 50 & $A$ \\
\hline 185 & 29 & 15 & $B$ & 190 & 38 & 20 & $B$ & 184 & 50 & 15 & $B$ \\
\hline 365 & 29 & 44 & $A$ & 260 & 30 & 50 & $A$ & 190 & 35 & 55 & $A$ \\
\hline
\end{tabular}

Creative Commons Attribution 4.0 International 
Continuation of Table 5

\begin{tabular}{|c|c|c|c|c|c|c|c|c|c|c|c|}
\hline \multicolumn{4}{|c|}{ Training sample } & \multicolumn{4}{|c|}{ Test sample } & \multicolumn{4}{|c|}{ Control sample } \\
\hline \multirow{2}{*}{$\begin{array}{l}\text { Packet resi- } \\
\text { dence time on } \\
\text { the routers, } \mu \mathrm{s}\end{array}$} & \multicolumn{2}{|c|}{$\begin{array}{c}\text { Total queue } \\
\text { delay, } \mu \mathrm{s}\end{array}$} & \multirow{2}{*}{ Route } & \multirow{2}{*}{$\begin{array}{l}\text { Packet resi- } \\
\text { dence time } \\
\text { on the rout- } \\
\quad \text { ers, } \mu \mathrm{s}\end{array}$} & \multicolumn{2}{|c|}{$\begin{array}{l}\text { Total queue } \\
\text { delay, } \mu \mathrm{s}\end{array}$} & \multirow{2}{*}{ Route } & \multirow{2}{*}{$\begin{array}{l}\text { Packet resi- } \\
\text { dence time } \\
\text { on the rout- } \\
\text { ers, } \mu \mathrm{s}\end{array}$} & \multicolumn{2}{|c|}{$\begin{array}{c}\text { Total queue } \\
\text { delay, } \mu \mathrm{s}\end{array}$} & \multirow{2}{*}{ Route } \\
\hline & $\begin{array}{c}\text { path } \\
A\end{array}$ & $\begin{array}{c}\text { path } \\
B\end{array}$ & & & $\begin{array}{c}\text { path } \\
A\end{array}$ & $\begin{array}{c}\text { path } \\
B\end{array}$ & & & $\begin{array}{c}\text { path } \\
A\end{array}$ & $\begin{array}{c}\text { path } \\
B\end{array}$ & \\
\hline 365 & 44 & 29 & $B$ & 360 & 50 & 30 & $B$ & 225 & 55 & 35 & $B$ \\
\hline 455 & 7 & 63 & $A$ & 370 & 45 & 60 & $A$ & 275 & 50 & 65 & $A$ \\
\hline 455 & 63 & 7 & $B$ & 385 & 60 & 45 & $B$ & 300 & 65 & 45 & $B$ \\
\hline 545 & 45 & 65 & $A$ & 470 & 56 & 70 & $A$ & 375 & 57 & 68 & $A$ \\
\hline 545 & 65 & 45 & $B$ & 540 & 70 & 56 & $B$ & 460 & 68 & 57 & $B$ \\
\hline$\ldots$ & $\ldots$ & $\ldots$ & $\ldots$ & $\ldots$ & $\ldots$ & $\ldots$ & $\ldots$ & & & & \\
\hline
\end{tabular}

\section{Findings}

Study of the average learning error of the NN1. MatLAB's Fuzzy Logic Toolbox includes 11 built-in membership functions that use the following basic functions: piecewise linear one; Gaussian distribution; sigmoid curve; quadratic and cubic curves. The values of the learning errors of NN1 for different membership functions are presented in Table 6. It can be seen from the table that the Gaussian membership function gives the smallest value of the NN1 error.

Table 6

Average error of NN1 according to different membership functions

\begin{tabular}{|c|c|c|}
\hline Membership function & Designation & Average NFN error, $10^{-10} \mathrm{sec}$ \\
\hline triangular & trimf & 8.75 \\
\hline trapezoidal & trapmf & 10.23 \\
\hline bell-shaped & gbellmf & 9.16 \\
\hline symmetric Gaussian & gaussmf & 8.49 \\
\hline two-sided Gaussian & gauss $2 \mathrm{mf}$ & 10.03 \\
\hline the product of two sigmoid membership functions & pimf & 13.86 \\
\hline Curvilinear trapezoid membership function & psigmf & 10.32 \\
\hline the difference between two sigmoid membership functions & dsigmf & 10.63 \\
\hline
\end{tabular}

The following methods of training optimization are implemented in ANFIS: backpropagation (method based on the ideas of the quickest descent method); hybrid (hybrid method that combines the backpropagation method with the least-squares method). When using the backpropagation method, the NN1 learning error is $9.6501 \cdot 10^{-10} \mathrm{sec}$ and the hybrid method $-8.4873 \cdot 10^{-10}$ sec. That is, the error of learning the NN1 in the case of using the hybrid method is about $13 \%$ less than in the case of the backpropagation method.

Evaluation of the work of the NN1. The NN1 simulation was performed with the following parameters: packet length -3850 bytes; traffic intensity -10 packet/sec; number of transitions -3 . The packet time on the route (from Fedorivka junction to Dnipro junction) received in the ORNET Modeler system on the Fast Ethernet simulation model in the ITS of Prydniprovska Railway under the 
OSPFE protocol is $0.0010285 \mathrm{sec}$. (Fig. 7), and based on NN1 $-0.000924 \mathrm{sec}$. (Fig. 8). That is, the use of NN1 allows approximately $10 \%$ faster determination of the route in the ITS network of
Prydniprovska Railway (for the fragment under consideration) as compared to the OSPF protocol on the simulation model.

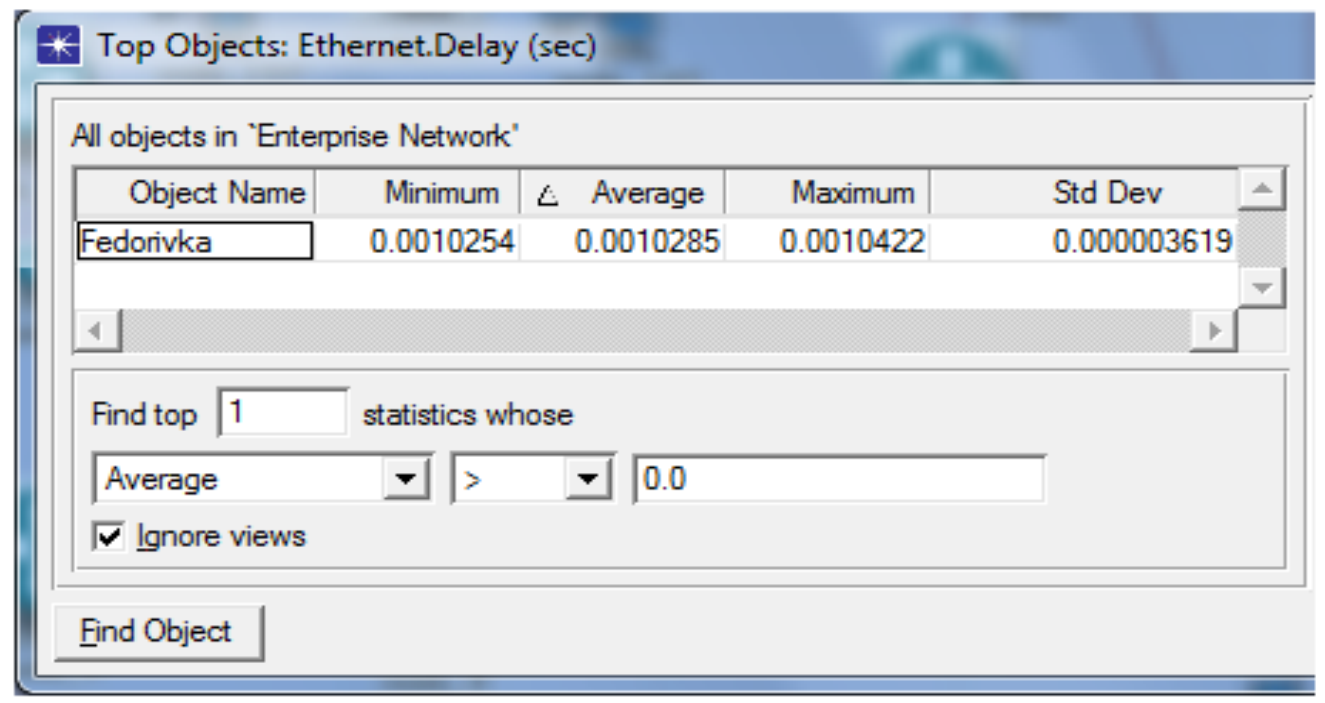

Fig. 7. Packet time on the route (from Fedorivka to Dnipro) obtained on the simulation model

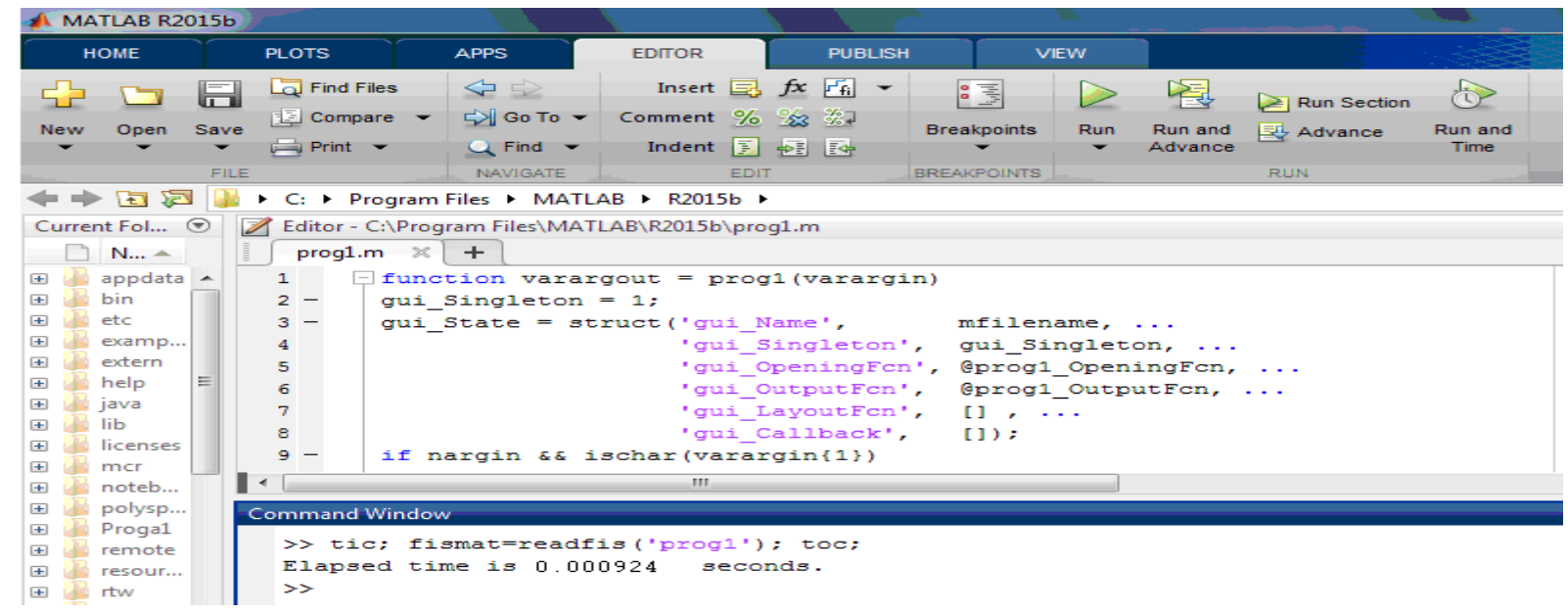

Fig. 8. Packet time on the route (from Fedorivka to Dnipro) obtained on the NN1

\section{Originality and practical value}

The simulation model of Fast Ethernet network based on the OSPF scenario and the neural fuzzy networks (NN1, NN2) can be the basis for the integrated routing system in the ITS network of Prydnprovska Railway, the general structure of which is shown in Fig. 9 ( $L$ pac - is the packet length; $\Lambda$ - is the traffic intensity; $K-$ is the number of intermediate routers that make up the path of the packet; Tpac - the packet residence time in the routers according to its path in the network; $Z \_A-$ total queue delay in the routers on the path $A ; Z_{-}$ $B$ - total queue delay in the routers on the path $B$ ).

The operation of the integrated routing system is demonstrated for those fragments of the Fast Ethernet network in the ITS of Prydniprovska Railway, where it is possible to choose the route with the same number of intermediate routers on different paths (Table 7: path $A$ - to the right). 


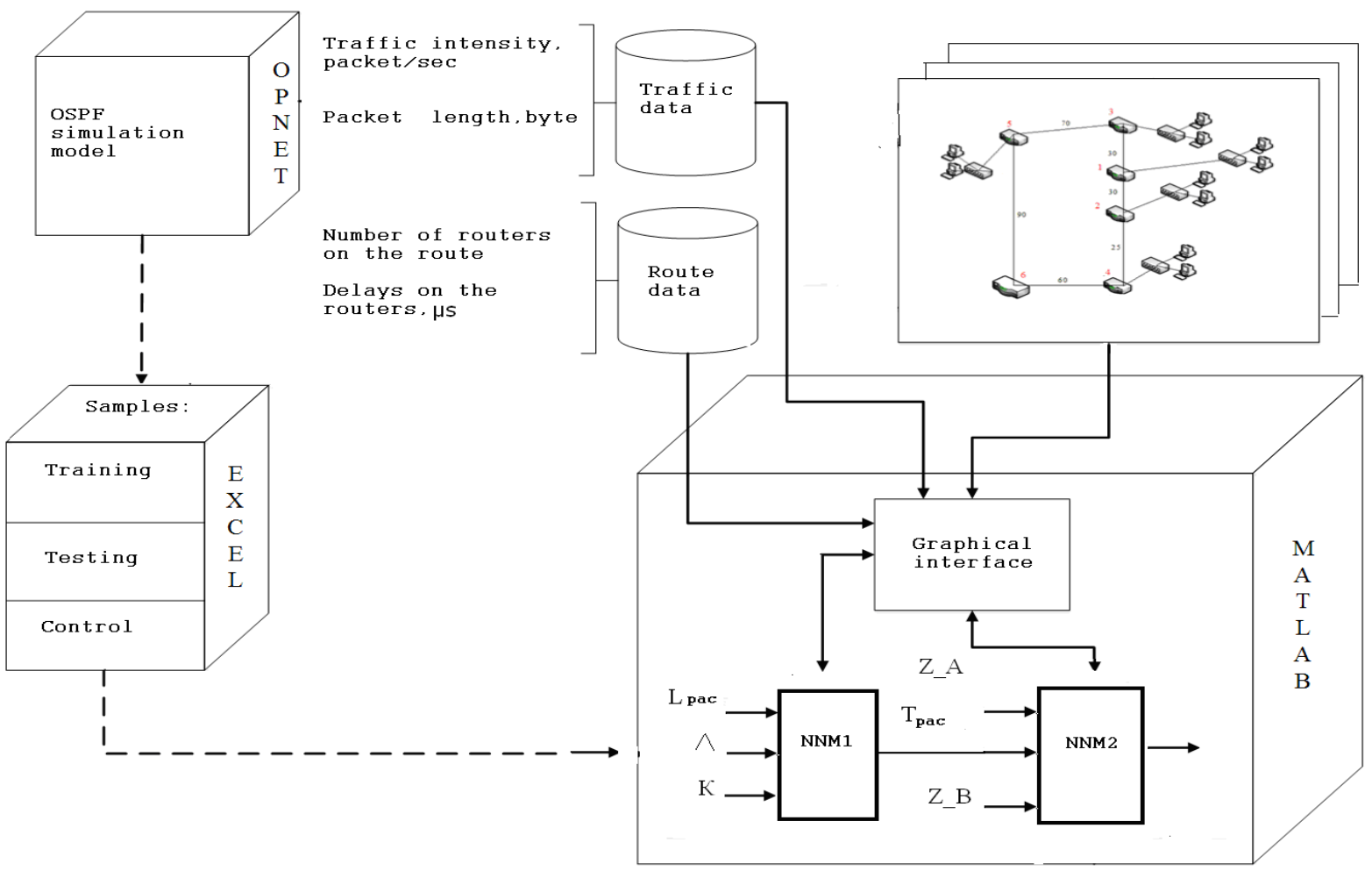

Fig. 9. General structure of the integrated routing system in the ITS network of railway transport: - - - preparatory stage; - real time work

Nyzhnodniprovsk-Vuzol - Dnipro fragment. A packet of 500 bytes, with a traffic intensity of 10 packets/sec and 2 transitions is transmitted from the node $V 1$ (Ihren) to the node $V 6$ (Dnipro). The packet residence time on the routers is predicted by $\mathrm{NN} 1$ and is $80 \mu \mathrm{s}$. For example, depending on the values of the time received, the total queue delay in the routers on the path $A(4 \mu \mathrm{s})$ and the total queue delays in the routers on the path $B(13 \mu \mathrm{s})$ the optimal route is chosen based on NN2: path $A$. The graph showing the fragment «NyzhnodniprovskVuzol - Dnipro» shows this route in red: $V 1 \rightarrow V 2 \rightarrow V 4 \rightarrow V 6$.

Horiainove fragment. A packet of 1000 bytes, with an intensity of 10 packets/sec and 4 transitions, is transmitted from the node $V 1$ (Kamianske-Pas) to the node $V 10$ (Dnipro). The packet residence time in the routers is predicted by NN1, it is $320 \mu \mathrm{s}$. Depending on the values of the time received, the total queue delay in the routers on the path $A(29 \mu \mathrm{s})$ and the total queue delay in the routers on the path route $B(20 \mu \mathrm{s})$ the optimal route is chosen based on NN2: path $B$. The graph showing the fragment «Horiainove» shows this route in red: $V 1 \rightarrow V 2 \rightarrow V 7 \rightarrow V 8 \rightarrow V 9 \rightarrow V 10$.

Kryvyi Rih fragment. A packet of 1500 byte, with an intensity of 10 packets/sec and 2 transitions, is transmitted from the node $V 1$ (Vechirnii Kut) to the node V6 (Dnipro). The packet residence time in the routers is predicted by NN1, it is 240 $\mu \mathrm{s}$. For example, depending on the values of the time received, the total queue delay in the routers on the path $A(30 \mu \mathrm{s})$ and the total queue delay in the routers on the path $B(50 \mu \mathrm{s})$ the optimal route is chosen based on NN2: path $A$. The graph showing the fragment «Nyzhnodniprovsk-Vuzol Dnipro» shows this route in red: $V 1 \rightarrow V 2 \rightarrow V 3 \rightarrow V 6$. 


\section{Consideration of the ITS fragments of Prydniprovska Railway}

\begin{tabular}{|c|c|c|c|c|}
\hline & NN1 & $\mathrm{NN} 2$ & Fragment structure & Designations \\
\hline \multicolumn{5}{|c|}{ Nyzhnodniprovsk-Vuzol - Dnipro fragment } \\
\hline \multirow[t]{3}{*}{$\begin{array}{l}\text { Input pa- } \\
\text { rameters }\end{array}$} & $\begin{array}{c}500 \\
\text { bytes }\end{array}$ & $80 \mu \mathrm{s}$ & E5 & $\begin{array}{c}V 1-\text { Ihren; } \\
V 2-\text { Ilarionove; }\end{array}$ \\
\hline & $\begin{array}{c}10 \\
\text { pack- } \\
\text { et/sec }\end{array}$ & $4 \mu \mathrm{s}$ & E1 & $\begin{array}{c}\text { V3 - Nyzhnodniprovsk- } \\
\text { Vuzol; } \\
\text { V4 - Synelnykove }-2 ;\end{array}$ \\
\hline & 2 & $13 \mu \mathrm{s}$ & & V - INyZmIIOUIIPIOVSK, \\
\hline Result & $80 \mu \mathrm{s}$ & $\begin{array}{c}1 \\
(\text { path } A)\end{array}$ & $\mathrm{E} 2$ & ro Dimpio \\
\hline
\end{tabular}

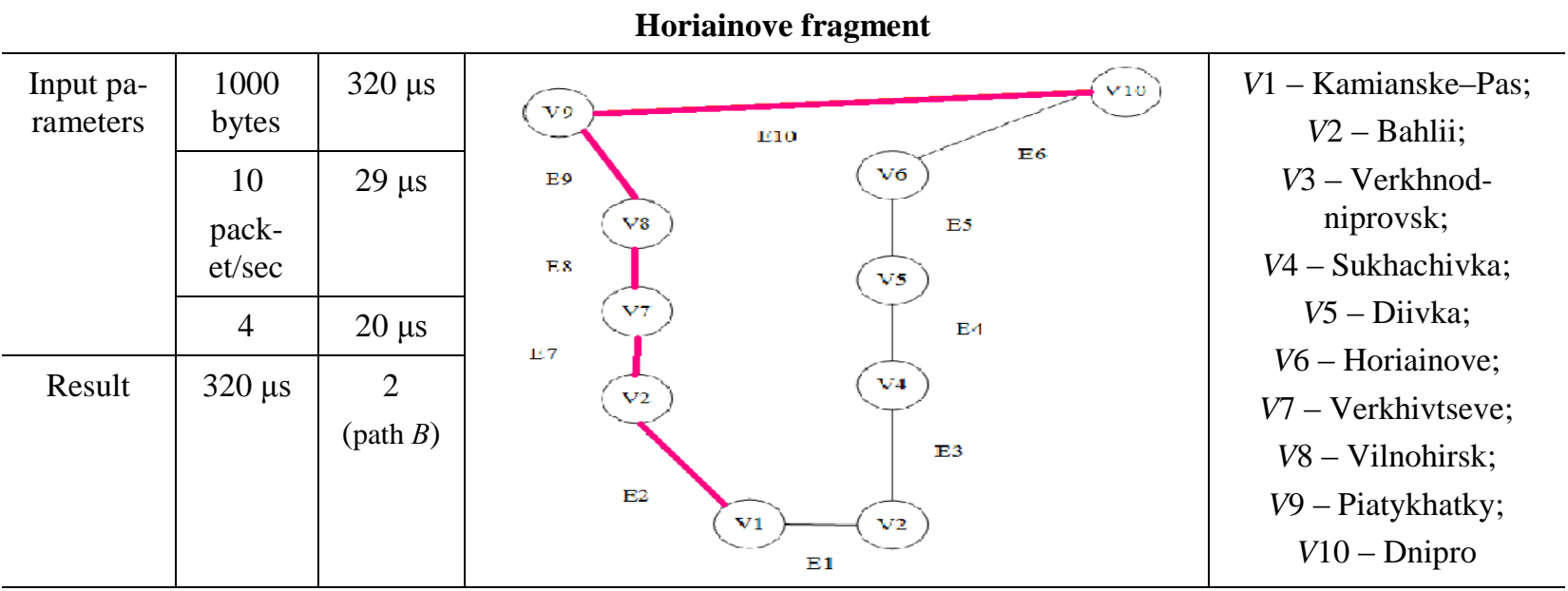

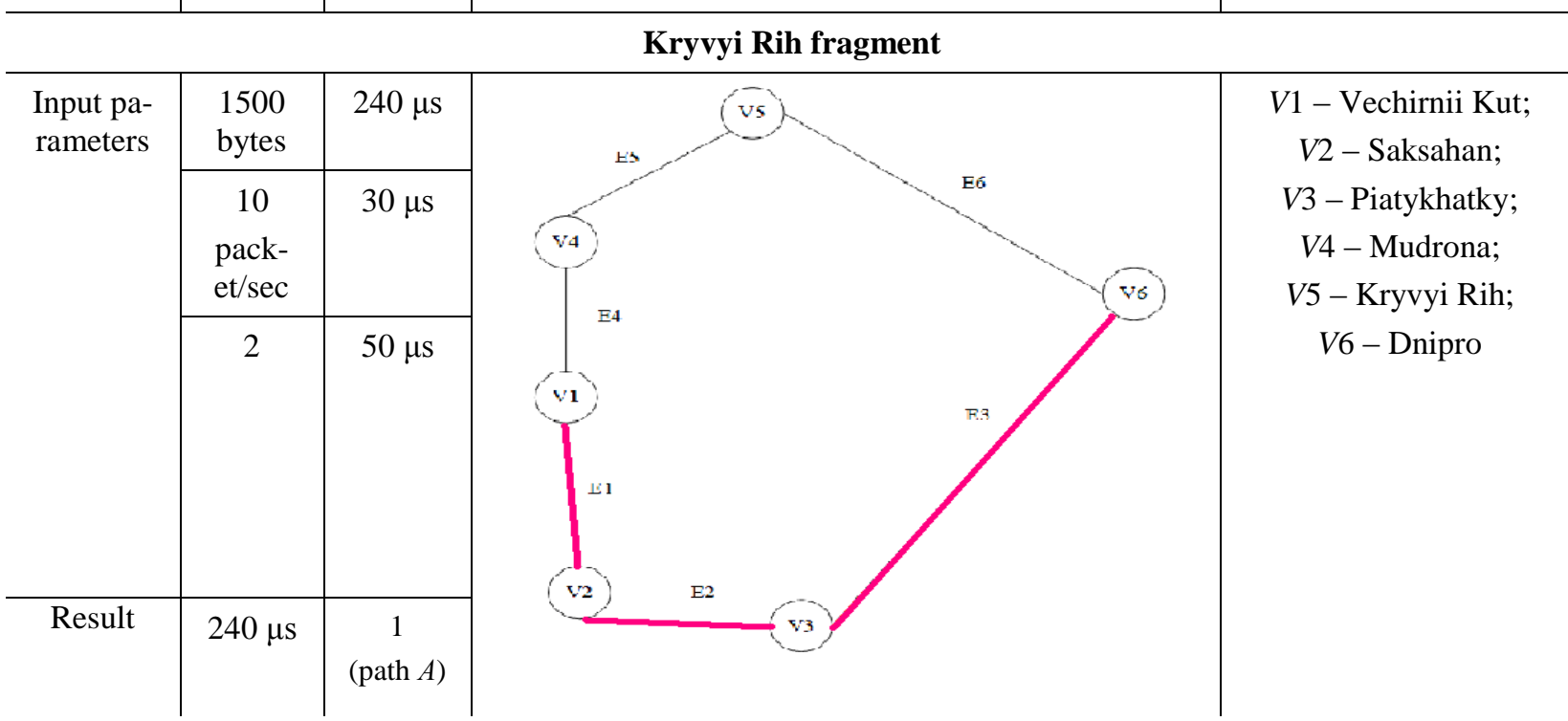




\section{Conclusions}

1. According to the structure of the ITS network of Prydniprovska Railway, a corresponding Fast Ethernet simulation model (according to the RIP and OSPF scenarios) was created in the ORNET Modeler system, which defines the following characteristics: average server load; the average time of packet processing by router; average waiting time for packets in the queue; the average number of lost packets. It is determined that the worst results are obtained by the simulation model according to the RIP scenario: server load increases rapidly (on average, about by 3 times per minute); packet processing time by router takes much longer (approximately by 0.5 times per minute); the waiting time for packets in the queue is always greater (about by 1.6 times per minute); packet losses increase rapidly (on average by 3.5 times per minute); the network convergence time is almost twice as large.

2. To determine the packet residence time in the routers on the route by its transmission in the ITS network of the Prydniprovska Railway NN1 was created, to the input of which the following parameters are supplied: packet length (3 term sets); traffic intensity (5 term sets); the number of intermediate routers in the route (4 term sets). The following samples were formed on the simulation model of the ITS network of Prydniprovska Railway: training (60 examples), test (24 examples) and control (12 examples). It has been estimated that for the considered fragment of the railway ITS network, in particular Prydniprovska Railway, the packet time on the route based on NN1 decreased by about $10 \%$ compared to the OSPF protocol on the simulation model.

3. On the created NN1 the study of the average error of its training for different membership functions was performed: triangular; trapezoidal; bell-shaped; symmetric and two-sided Gaussian and by different methods of training optimization (hybrid and backpropagation). It is determined that the lowest value of the average error $8.4873 \cdot 10^{-10}$ sec NN1 gives in the case of using the symmetric Gaussian membership function according to the hybrid optimization method.

4. To determine the packet path in the ITS network of Prydniprovska Railway (provided the same number of routers that make up the path), the NN2 was created, to the input of which the following parameters are supplied: the packet time in the routers on the path of its transition, the total queue delay in the routers on the path $A$; the total queue delay in the routers on the path $B$. Using the simulation model of the ITS network of railway transport the following samples were formed: training (75 examples), test (20 examples) and control (10 examples).

5. Based on the created Fast Ethernet simulation model and neural fuzzy networks (NN1 and NN2), an integrated routing system was proposed in the ITS of Prydniprovska Railway was proposed. Using this system, for example, the optimal route for the fragment «Nyzhnodniprovsk-Vuzol Dnipro» is determined: path A (Ihren, Ilarionove, Synelnykove-2, Dnipro)».

\section{LIST OF REFERENCE LINKS}

1. Асланов, А. М. Исследование интеллектуального подхода в маршрутизации компьютерных сетей / А. М. Асланов, М. С. Солодовник // Электротехнические и компьютерные системы. - 2014. - № 16 (92). - C. 93-100.

2. Коваленко, Т. А. Разработка и исследование интегрированной системы маршрутизации в компьютерных сетях : автореф. дис. ... канд. техн. наук : 05.13.15 / Коваленко Татьяна Анатольевна ; СГУ. - Самаpa, 2012. - $16 \mathrm{c}$.

3. Колесніков, К. В. Аналіз результатів дослідження реалізації задачі маршрутизації на основі нейронних мереж та генетичних алгоритмів / К. В. Колесніков, А. Р. Карапетян, В. Ю. Баган // Вісн. Черкас. держ. технол. ун-ту. Серія: Технічні науки : зб. наук. пр. - Черкаси, 2016. - № 1. - С. 28-34.

4. Кутыркин, А. В. Использование нейронной сети Хопфилда для решения оптимизационных задач маршрутизации : метод. указания / А. В. Кутыркин, А. В. Семин. - Москва : Изд-во Моск. гос. ун-та путей сообщения, 2007. - 15 с.

5. Никитченко, В. В. Утилиты моделирующей системы Opnet Modeler / В. В. Никитченко. - Одесса : Одес. нац. акад. связи им. А. С. Попова, 2010. - 128 с. 
6. Павленко, М. А. Анализ возможностей искусственных нейронных сетей для решения задач однопутевой маршрутизации в ТКС [Electronic resource] / М. А. Павленко // Проблеми телекомунікацій. - 2011. - № 2 (4). - Available at: http://pt.journal.kh.ua/index/0-139 - Title from the screen. - Accessed : 26.09.2019.

7. Пахомова, В. М. Дослідження інформаційно-телекомунікаційної системи залізничного транспорту 3 використанням штучного інтелекту : монографія / В. М. Пахомова. - Дніпро : Стандарт-Сервіс, 2018. $220 \mathrm{c}$.

8. Реалізація задачі вибору оптимального авіамаршруту нейронною мережею Хопфілда / А. М. Бриндас, П. І. Рожак, Н. О. Семенишин, Р. Р. Курка // Наук. вісн. НЛТУ України : зб. наук.-техн. пр. - Львів, 2016. - Вип. 26.1. - С. 357-363.

9. Тарасян, В. С. Пакет Fuzzy Logic Toolbox for MatLAB : учебное пособие / В. С. Тарасян. - Екатеринбург : Изд-во УрГУПС, 2013. - 112 с.

10. Штовба, С. Д. Проектирование нечетких систем средствами MatLAB / С. Д. Штовба. - Москва : Горячая линия - Телеком, 2007. - 288 с.

11. Hopfield, J. J. Neural networks and physical systems with emergent collective computational abilities / J. J. Hopfield // Proceedings of National Academy of Sciences. - 1982. - Vol. 79. - Iss. 8. - P. 2554-2558. doi: 10.1073/pnas.79.8.2554

12. Iqbal, A. Performance Evaluation of Real Time Applications for RIP, OSPF and EIGRP for flapping links using OPNET Modeler [Electronic resource] // A. Iqbal, S. L. Ali Khan / International Journal of Computer Networks and Communications Security. - 2015. - Vol. 3, No. 1. - Available at: http://www.ijcncs.org/published/volume3/issue1/p4_3-1.pdf - Title from the screen. - Accessed : 26.09.2019

13. Kumar, M. V. Soft Computing: Fuzzy Logic Approach in Wireless Sensors Networks / M. V. Kumar, Dr. T. Lalitha // Circuits and Systems. - 2016. - Vol. 07. - Iss. 08. - P. 1242-1249. doi: https://doi.org/10.4236/cs.2016.78108

14. New algorithm for packet routing in mobile ad-hoc networks / N. S. Kojić, M. B. Zajeganović-Ivančić, I. S. Reljin, B. D. Reljin // Journal of Automatic Control. - 2010. - Vol. 20. - Iss. 1. - P. 9-16. doi: 10.2298/JAC1001009K

15. Pakhomova, V. M. Intelligent routing in the network of information and telecommunication system of railway transport / V. M. Pakhomova, T. I. Skaballanovich, V. S. Bondareva // Наука та прогрес транспорту. - 2019. - № 2 (80). - P. 77-90. doi: 10.15802/stp2019/166092

16. Pakhomova, V. M. Optimal route definition in the network based on the multilayer neural model / V. M. Pakhomova, I. D. Tsykalo // Наука та прогрес транспорту. - 2018. - № 6 (78). - P. $126-142$. doi: $10.15802 /$ stp2018/154443

17. Sasikala, K. A neuro fuzzy based conditional shortest path routing protocol for wireless mesh network / K. Sasikala, V. Rajamani // International Journal of Enhanced Research in Management \& Computer Applications. -2013. - Vol. 2. - Iss. 5. - P. 1-10.

18. Schuler, W. H. A novel hybrid training method for hopfield neural networks applied to routing in communications networks / W. H. Schuler, C. J. A. Bastos-Filho, A. L. I. Oliveira // International Journal of Hybrid Intelligent Systems. - 2009. - Vol. 6. - Iss. 1. - P. 27-39. doi: 10.3233/his-2009-0074

19. Towards QoS-aware routing for DASH utilizing MPTCP over SDN / K. Herguner, R. S. Kalan, C. Cetinkaya, M. Sayit // IEEE Conference on Network Function Virtualization and Software Defined Networks (NFVSDN) (6-8 Nov. 2017). - Berlin, Germany, 2017. - P. 1-6. doi: 10.1109/nfv-sdn.2017.8169844

20. Zhukovyts'kyy, I. Research of Token Ring network options in automation system of marshalling yard / I. Zhukovyts'kyy, V. Pakhomova // Transport Problems. - 2018. - Vol. 13. - Iss. 2. - P. 149-158.

\section{В. М. ПАХОМОВА ${ }^{1 *}$, С. С. МАНДИБУРА ${ }^{2 *}$}

\footnotetext{
1*Каф. «Електронні обчислювальні машини», Дніпровський національний університет залізничного транспорту імені академіка В. Лазаряна, вул. Лазаряна, 2, Дніпро, Україна, 49010, тел. +38 (056) 3731589 , ел. пошта viknikpakh@gmail.com, ORCID 0000-0002-0022-099X

${ }^{2 *}$ Каф. «Електронні обчислювальні машини», Дніпровський національний університет залізничного транспорту імені академіка В. Лазаряна, вул. Лазаряна, 2, Дніпро, Україна, 49010, тел. +38 (056) 37315 89, ел. пошта mandybura1994@gmail.com, ORCID 0000-0002-7134-9416
} 


\section{ВИЗНАЧЕННЯ ОПТИМАЛЬНОГО МАРШРУТУ В ІНФОРМАЦЙННЙ МЕРЕЖІ ЗАЛІЗНИЧНОГО ТРАНСПОРТУ 3 ВИКОРИСТАННЯМ НЕЙРОНЕЧІТКИХ МОДЕЛЕЙ}

Мета. Сучасні алгоритми вибору найкоротшого маршруту, наприклад, алгоритми Беллмана-Форда й Дейкстри, які в даний час широко використовують у протоколах маршрутизації (RIP, OSPF), не завжди призводять до ефективного результату. Тому виникає необхідність дослідження можливості організації маршрутизації в мережі інформаційно-телекомунікаційної системи (ITC) залізничного транспорту за допомогою методів штучного інтелекту. Методика. На основі створеної в моделювальній системі OPNET імітаційної моделі розглянуто фрагмент мережі ITC залізничного транспорту й сформовано наступні вибірки: навчальну; тестувальну; контрольну. Для моделювання в системі MatLAB нейронечіткої мережі (гібридної системи) на вхід подають наступні параметри: довжина пакета (3 терм-множини); інтенсивність трафіка (5 терм-множин); кількість проміжних маршрутизаторів, що складають маршрут (4 терм-множини). За результуючу характеристику взято час перебування пакета в маршрутизаторах за маршрутом його проходження в мережі ITC (4 терм-множини). На основі визначеного часу перебування пакета в маршрутизаторах і затримок у черзі на маршрутизаторах, що складають різні шляхи (з однаковою кількістю маршрутизаторів) визначено оптимальний маршрут. Результати. Для розглянутого фрагмента ITС залізничного транспорту здійснено прогноз часу перебування пакета в маршрутизаторах за маршрутом його проходження на основі нейронечіткої мережі, що створена в системі MatLAB. Проведено дослідження середньої похибки навчання нейронечіткої мережі за різних функцій належності й за різними методами оптимізації навчання. Виявлено, що найменше значення середньої похибки навчання надає нейронечітка мережа конфігурації 3-12-60-60-1 в разі використання симетричної Гаусівської функції належності за гібридним методом оптимізації. Наукова новизна. За сценаріями RIP та OSPF на створеній в моделювальній системі OPNET імітаційній моделі отримані наступні характеристики: середнє навантаження сервера; середній час обробки пакетів маршрутизатором; середній час очікування пакетів у черзі; середня кількість втрачених пакетів; час конвергенції мережі. Визначено, що найкращі результати надає імітаційна модель мережі за сценарієм OSPF. Запропонована інтегрована система маршрутизації в мережі ITC залізничного транспорту, в основу якої покладено створені нейронечіткі мережі, визначає оптимальний маршрут у мережі швидше порівняно 3 наявним протоколом маршрутизації OSPF. Практична значимість. Інтегрована система маршрутизації в ITC залізничного транспорту дозволить у реальному часі визначити оптимальний маршрут у мережі за однаковою кількістю маршрутизаторів, що складають шлях проходження пакета.

Ключові слова: маршрутизація; протокол OSPF; імітаційна модель; гібридна система; терм; функція належності; вибірка; похибка

\section{В. Н. ПАХОМОВА ${ }^{1 *}$ Е. С. МАНДЫБУРА ${ }^{2 *}$}

\footnotetext{
${ }^{1 *}$ Каф. «Электронные вычислительные машины», Днипровский национальный университет железнодорожного транспорта имени академика В. Лазаряна, ул. Лазаряна, 2, Днипро, Украина, 49010, тел. +38 (056) 3731589 , эл. почта viknikpakh@gmail.com, ORCID 0000-0002-0022-099X

${ }^{2 *}$ Каф. «Электронные вычислительные машины», Днипровский национальный университет железнодорожного транспорта имени академика В. Лазаряна, ул. Лазаряна, 2, Днипро, Украина, 49010, тел. +38 (056) 3731589 , эл. почта mandybura1994@gmail.com, ORCID 0000-0002-7134-9416
}

\section{ОПРЕДЕЛЕНИЕ ОПТИМАЛЬНОГО МАРШРУТА В ИНФОРМАЦИОННОЙ СЕТИ ЖЕЛЕЗНОДОРОЖНОГО ТРАНСПОРТА С ИСПОЛЬЗОВАНИЕМ НЕЙРОНЕЧЕТКИХ МОДЕЛЕЙ}

Цель. Современные алгоритмы выбора кратчайшего маршрута, например, алгоритмы Беллмана-Форда и Дейкстры, которые в настоящее время широко используют в протоколах маршрутизации (RIP, OSPF), не всегда приводят к эффективному результату. Поэтому возникает необходимость исследования возможности организации маршрутизации в сети информационно-телекоммуникационной системы (ИТС) железнодорож- 
ного транспорта с помощью методов искусственного интеллекта. Методика. На основе созданной в моделирующей системе OPNET имитационной модели рассмотрен фрагмент сети ИТС железнодорожного транспорта и сформированы следующие выборки: обучающая; тестирующая; контрольная. Для моделирования в системе MatLAB нейронечеткой сети (гибридной системы) на вход подают следующие параметры: длина пакета (3 терм-множества); интенсивность трафика (5 терм-множеств); количество промежуточных маршрутизаторов, составляющих маршрут (4 терм-множества). В качестве результирующей характеристики принято время пребывания пакета в маршрутизаторах по маршруту его следования в сети ИТС (4 терммножества). На основе полученного времени пребывания пакета в маршрутизаторах и задержек в очереди на маршрутизаторах, составляющих различные пути (с одинаковым количеством маршрутизаторов) определен оптимальный маршрут. Результаты. Для рассматриваемого фрагмента ИТС железнодорожного транспорта осуществлен прогноз времени пребывания пакета в маршрутизаторах по маршруту его следования на основе нейронечеткой сети, созданной в системе MatLAB. Проведено исследование средней погрешности обучения нейронечеткой сети при различных функциях принадлежности и разных методов оптимизации обучения. Обнаружено, что наименьшее значение средней погрешности обучения предоставляет нейронечеткая сеть конфигурации 3-12-60-60-1 при использовании симметричной Гауссовской функции принадлежности с гибридным методом оптимизации. Научная новизна. По сценариям RIP и OSPF на созданной в моделирующей системе OPNET имитационной модели получены следующие характеристики: средняя нагрузка сервера; среднее время обработки пакетов маршрутизатором; среднее время ожидания пакетов в очереди; среднее количество потерянных пакетов; время конвергенции сети. Определено, что наилучшие результаты дает имитационная модель сети по сценарию OSPF. Предложенная интегрированная система маршрутизации в сети ИТС железнодорожного транспорта, в основу которой положены созданные нейронечеткие модели, определяет оптимальный маршрут в сети быстрее по сравнению с существующим протоколом маршрутизации OSPF. Практическая значимость. Интегрированная система маршрутизации в ИТС железнодорожного транспорта позволит в реальном времени определить оптимальный маршрут в сети с одинаковым количеством маршрутизаторов, составляющих путь прохождения пакета.

Ключевые слова: маршрутизация; протокол OSPF; имитационная модель; гибридная система; терм; функция принадлежности; выборка; погрешность

\section{REFERENCES}

1. Aslanov, A. M., \& Solodovnik, M. S. (2014). Issledovanie intellektualnogo podkhoda v marshrutizatsii kompyuternykh setey. Elektrotekhnicheskie i kompyuternye sistemy, 16(92), 93-100. (in Russian)

2. Kovalenko, T. A. (2012). Razrabotka i issledovanie integrirovannoy sistemy marshrutizatsii v kompyuter-nykh setyakh. (Avtoreferat dysertatsii kandydata tekhnichnykh nauk). SGU, Samara. (in Russian)

3. Kolesnikov, K. V., Karapetian, A. R., \& Bahan, V. Y. (2016). Analiz rezultativ doslidzhennia realizatsii zadachi marshrutyzatsii na osnovi neironnykh merezh ta henetychnykh alhorytmiv. Visnyk Cherkaskogo derzhavnogo tehnologichnogo universitetu. Seria: Tehnichni nauky, 1, 28-34. (in Ukrainian)

4. Kutyrkin, A. V., \& Semin, A. V. (2007). Ispolzovanie neyronnoy seti Khopfilda dlya resheniya optimizatsionnykh zadach marshrutizatsii: Metodicheskie ukazaniya. Moscow: Izdatelstvo Moskovskogo gosudarstvennogo universiteta putey soobshcheniya. (in Russian)

5. Nikitchenko, V. V. (2010). Utility modeliruyushchey sistemy Opnet Modeler. Odessa: Odesskaya natsionalnaya akademiya svyazi im. A. S. Popova. (in Russian)

6. Pavlenko, M. A. (2011). Analysis opportunities of artificial neural networks for solving single-path routing in telecommunication network. Problemy telekomunikatsii, 2(4). Retrieved from http://pt.journal.kh.ua/index/ $0-139$ (in Russian)

7. Pakhomova, V. M. (2018). Doslidzhennia informatsiino-telekomunikatsiinoi systemy zaliznychnoho transportu z vykorystanniam shtuchnoho intelektu: monohrafiia. Dnipro: Standart-Servis. (in Ukrainian)

8. Bryndas, A. M., Rozhak, P. I., Semenishin, N. O., \& Kurka, R. R. (2016). Implementing of the Problem of Choosing the Optimal Flight Rout by a Hopfield Neural Network. The Scientific Bulletin of UNFU, 26.1, $357-$ 363. (in Ukrainian)

9. Tarasyan, V. S. Paket Fuzzy Logic Toolbox for MatLAB: uchebnoe posobie. (2013) Yekaterinburg: Izdatelstvo: UrGUPS. (in Russian)

10. Shtovba, S. D. (2007). Proektirovanie nechetkikh sistem sredstvami MatLAB. Moscow: Goryachaya liniyaTelekom. (in Russian) 
11. Hopfield, J. J. (1982). Neural networks and physical systems with emergent collective computational abilities. Proceedings of National Academy of Sciences, 79(8), 2554-2558. doi: https://doi.org/10.1073/pnas.79.8.2554 (in English)

12. Iqbal, A., \& Ali Khan, S. L. (2015). Performance Evaluation of Real Time Applications for RIP, OSPF and EIGRP for flapping links using OPNET Modeler. International Journal of Computer Networks and Communications Security, 3(1). Retrieved from: http://www.ijcncs.org/published/volume3/issue1/p4_3-1.pdf (in English)

13. Kumar, M. V., \& Lalitha, Dr. T. (2016). Soft Computing: Fuzzy Logic Approach in Wireless Sensors Networks. Circuits and Systems, 07(08), 1242-1249. doi: https://doi.org/10.4236/cs.2016.78108 (in English)

14. Kojić, N. S., Zajeganović-Ivančić, M. B., Reljin, I. S., \& Reljin B. D. (2010). New algorithm for packet routing in mobile ad-hoc networks. Journal of Automatic Control, 20(1), 9-16. doi: https://doi.org/10.2298/jac1001009k (in English)

15. Pakhomova, V. M., Skaballanovich, T. I., \& Bondareva, V. S. (2019). Intelligent routing in the network of information and telecommunication system of railway transport. Science and Transport Progress, 2(80), $77-$ 90. doi: https://doi.org/10.15802/stp2019/166092 (in English)

16. Pakhomova, V. M. \& Tsykalo, I. D. (2018). Optimal route definition in the network based on the multilayer neural model. Science and Transport Progress, 6(78), 126-142. doi: https://doi.org/10.15802/stp2018/154443 (in English)

17. Sasikala, K. \& Rajamani, V. (2013). A neuro fuzzy based conditional shortest path routing protocol for wireless mesh network. International Journal of Enhanced Research in Management \& Computer Applications, 2(5), 1-10. (in English)

18. Schuler, W. H., Bastos-Filho, C. J. A., \& Oliveira, A. L. I. (2009). A novel hybrid training method for hopfield neural networks applied to routing in communications networks. International Journal of Hybrid Intelligent Systems, 6(1), 27-39. doi: https://doi.org/10.3233/his-2009-0074 (in English)

19. Herguner, K., Kalan, R. S., Cetinkaya, C., \& Sayit, M. (2017). Towards QoS-aware routing for DASH utilizing MPTCP over SDN. 2017 IEEE Conference on Network Function Virtualization and Software Defined Networks (NFV-SDN). doi: https://doi.org/10.1109/nfv-sdn.2017.8169844 (in English)

20. Zhukovyts'kyy, I. \& Pakhomova, V. (2018). Research of Token Ring network options in automation system of marshalling yard. Transport Problems, 13(2), 145-154. (in English)

Received: May 15, 2019

Accepted: September 12, 2019 